\title{
Phylogenetic Analysis of Five Strains of Gram-Negative, Obligately Anaerobic, Sulfur-Reducing Bacteria and Description of Desulfuromusa gen. nov., Including Desulfuromusa kysingii sp. nov., Desulfuromusa bakii sp. nov., and Desulfuromusa succinoxidans sp. nov.
}

WERNER LIESACK ${ }^{1 *}$ AND KAI FINSTER ${ }^{2}$

Max-Planck-Institut für Terrestrische Mikrobiologie, D-35043 Marburg, Germany, ${ }^{1}$ and Institute of Biological Sciences, Department of Microbial Ecology, University of Arhus C, Arhus, Denmark ${ }^{2}$

\begin{abstract}
Gram-negative, mesophilic, obligately anaerobic strains $\mathrm{Kysw2}^{\mathrm{T}}(\mathrm{T}=$ type strain), Kyval, and Kyprop isolated from an anoxic mud sample obtained from the Kysing Fjord south of Århus (Denmark) and strains Gyprop $^{\mathrm{T}}$ and Gylac ${ }^{\mathrm{T}}$ isolated from the Guayamas Basin (Gulf of California) all exhibit complete oxidation of a wide range of electron donors (e. g., dicarboxylic acids and amino acids) linked to stoichiometric reduction of elemental sulfur to hydrogen sulfide. A comparative 16S ribosomal DNA sequence analysis revealed that these five strains, together with a previously described isolate (strain Gö11), constitute a coherent cluster of descent. This cluster belongs phylogenetically to a branch of the delta subclass of the Proteobacteria and is characterized by members of the genera Pelobacter and Desulfuromonas. Within the cluster strains Kysw2 ${ }^{\mathrm{T}}$ and Kyval, strains Gyprop ${ }^{T}$ and Kyprop, and strains Gylac ${ }^{T}$ and Gö11 have identical 16S ribosomal DNA sequences. The levels of DNA-DNA relatedness were $89 \%$ between strains $\mathrm{Kysw2}^{\mathrm{T}}$ and $\mathrm{Kyval}$, $98 \%$ between strains Gyprop ${ }^{\mathrm{T}}$ and Kyprop, and $73 \%$ between strains Gylac $^{\mathrm{T}}$ and Gö11. The levels of DNA-DNA relatedness between members of the three DNA relatedness groups were less than $30 \%$. On the basis of genomic data and phenotypic characteristics, a new genus, Desulfuromusa, is described; this new genus includes three new species, for which the names Desulfuromusa kysingii, Desulfuromusa bakii, and Desulfuromusa succinoxidans are proposed. The type species of the genus Desulfuromusa is D. kysingii. Strains Kysw2 (= DSM 7343), Gyprop (= DSM 7345), and Gylac (= DSM 8270) are the type strains of D. kysingii, D. bakii, and D. succinoxidans, respectively.
\end{abstract}

A number of microorganisms belonging to various genera exhibit growth-linked sulfur respiration. Sulfur reducers that are affiliated with the genus Campylobacter (27), Sulfurospirillum deleyianum $(27,33)$, Shewanella putrefaciens (19), Pseudomonas mendocina (1), and the sulfur-utilizing sulfate-reducing members of the genus Desulfomicrobium (2) are bacteria that incompletely oxidize substrates and form acetate as an end product. Members of the genus Desulfurella are thermophilic sulfur-reducing bacteria that are capable of complete oxidation of substrates $(3,18,23)$. The only known mesophilic sulfur reducers that completely oxidize substrates belong to the genus Desulfuromonas $(10,21,31)$. In a recent study Finster and Bak described the isolation of five strains of gram-negative, mesophilic, obligately anaerobic bacteria from anoxic mud samples collected at the shallow Kysing Fjord south of Århus (Denmark) (strains Kysw2 $2^{\mathrm{T}}$ [ $\mathrm{T}=$ type strain], Kyval, and Kyprop) and at the Guayamas Basin (Gulf of California) from a depth of about 2,000 $\mathrm{m}$ (strains Gyprop ${ }^{\mathrm{T}}$ and $\mathrm{Gylac}^{\mathrm{T}}$ ) (9). These isolates all completely oxidize acetate, propionate, and a range of dicarboxylic acids and amino acids (e. g., succinate, maleate, alanine, and aspartate) and substrate oxidation is coupled to concomitant stoichiometric reduction of elemental sulfur to hydrogen sulfide. Compared with the five new isolates, Desulfuromonas spp. use a rather limited range of substrates; acetate, ethanol, propanol, butanol, betaine, and pyruvate are

\footnotetext{
* Corresponding author. Mailing address: Max-Planck-Institut für Terrestrische Mikrobiologie, Karl-von-Frisch-Strasse, D-35043 Marburg, Germany. Phone: 496421 287087. Fax: 496421161470.
}

utilized by some strains as electron donors. To date, Desulfuromonas acetoxidans and Desulfuromonas acetexigens are the only validly described species of this genus $(10,21)$. More species of this genus have been isolated, but these bacteria have only been mentioned with provisional names in review papers (for example, "Desulfuromonas thiophila" and "Desulfuromonas succinoxidans") $(22,30,31)$.

In this paper we describe the results of a comparative $16 \mathrm{~S}$ ribosomal DNA (rDNA) sequence analysis performed to elucidate the phylogenetic affiliation of the five new isolates, as well as the results of DNA-DNA relatedness studies. In addition, the 16S rDNA sequences of "Desulfuromonas succinoxidans" Gö11 and Pelobacter carbinolicus GraBd1 $1^{\mathrm{T}}$ (24) were determined for reference purposes. On the basis of phylogenetic data and phenotypic characteristics the new genus Desulfuromusa is described below. The results of our DNA-DNA relatedness studies indicated that the five new isolates and strain Gö11 are members of three genomic species belonging to the genus Desulfuromusa, for which we propose the names Desulfuromusa kysingii, Desulfuromusa bakii, and Desulfuromusa succinoxidans.

\section{MATERIALS AND METHODS}

Bacterial strains. Strains Kysw2 ${ }^{\mathrm{T}}\left(=\mathrm{DSM} 7343^{\mathrm{T}}\right)$ (Deutsche Sammlung von Mikroorganismen und Zellkulturen GmbH, Braunschweig, Germany), Kyval (= DSM 7344), Gyprop $^{\mathrm{T}}\left(=\right.$ DSM $\left.7345^{\mathrm{T}}\right)$, Kyprop, and Gylac ${ }^{\mathrm{T}}(=\mathrm{DSM}$ $8270^{\mathrm{T}}$ ) were isolated and cultivated as described by Finster and Bak (9). Strain Gö11 was obtained from N. Pfennig, 
TABLE 1. Similarity matrix based on 16S rRNA sequence data

\begin{tabular}{|c|c|c|c|c|c|c|c|c|c|c|c|c|c|c|c|c|c|c|c|c|}
\hline \multirow[b]{2}{*}{ Species } & \multicolumn{20}{|c|}{$\%$ Similarity or $\%$ difference ${ }^{a}$} \\
\hline & 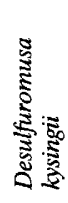 & 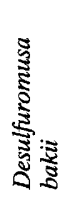 & 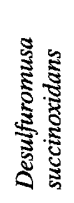 & 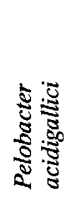 & 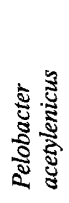 & 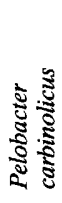 & 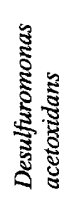 & 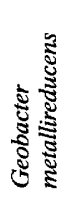 & 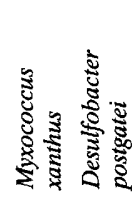 & 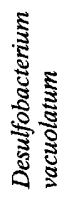 & 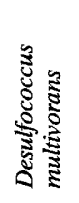 & 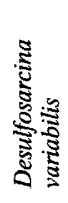 & 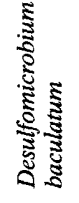 & 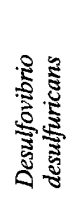 & 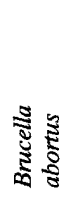 & 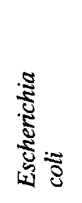 & 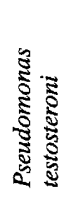 & 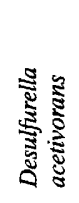 & 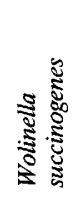 & 芯㺼 \\
\hline es & & 5 & 8.7 & 6.2 & 4.7 & 4.2 & 3.2 & 3.0 & 87.387 .3 & 86.6 & 8.4 & 89.0 & 88.0 & & 85.9 & 86.0 & 83.2 & 4.1 & 32.6 & 83 \\
\hline Desi & 0.5 & & 98.7 & 96.2 & 4.6 & 1.2 & 93.0 & 3.0 & 87.287 .5 & 86.7 & 88.2 & 88.7 & 88.1 & 2 & 86.0 & 85.7 & 83.1 & & 82.7 & s \\
\hline Desulfuromusa & 1.3 & 1.3 & & 96.3 & 94.4 & 94.0 & 93.6 & 92.8 & 87.287 .3 & 86.9 & 88.3 & 89.4 & 88.1 & 87.0 & 86.1 & 85.8 & 83.5 & 84.6 & 82.8 & 4.0 \\
\hline cter acid & 3.9 & 3.9 & 3.7 & & 94.4 & 94.2 & 93.1 & 93.2 & 87.187 .5 & 86.9 & 88.5 & 89.7 & 88.2 & 86.6 & 86.5 & 85.6 & 82.4 & 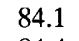 & 3.1 & 2.9 \\
\hline & 5.5 & 5.6 & 5.9 & 5.9 & & 98.4 & 94.8 & 93.7 & 88.688 .6 & 86.6 & 89.3 & 89.0 & 7 & 5 & 85.8 & 85.8 & 82.5 & 4 & .5 & 4.9 \\
\hline carbinol & 6.1 & 6.1 & 6.3 & 6.1 & 1.6 & & 94.8 & 93.5 & 88.688 .2 & 86.6 & 88.6 & 88.6 & 88.5 & 87.1 & 85.8 & 85.8 & 82.4 & 3.7 & 81.2 & 85.5 \\
\hline dan. & 7.1 & 7.3 & 6.6 & 7.2 & 5.4 & 5.4 & & 93.5 & 88.588 .1 & 86.1 & 88.1 & 88.3 & 87.8 & 87.0 & 84.6 & 85.5 & 82.6 & 1.3 & 2.3 & 85.6 \\
\hline 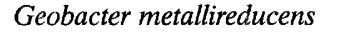 & 7.3 & 7.3 & 7.6 & 7.1 & 6.5 & 6.8 & 6.8 & & $87.6 \quad 87.8$ & 86.3 & 89.6 & 89.3 & 87.9 & 86.0 & 84.2 & 85.4 & 83.1 & 3.5 & 2.5 & 84.8 \\
\hline & 13.9 & 14.1 & 14.1 & 14.2 & 12.3 & 12.3 & 12.4 & 13.6 & 84.4 & 82.5 & 84.9 & 85.2 & 84.5 & 83.7 & 82.6 & 83.1 & 81.3 & 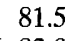 & 0.7 & 82.9 \\
\hline & 9 & 13.7 & 13.9 & 13.7 & 12.3 & 12.8 & 12.9 & 13.3 & 17.5 & 91.1 & 89.0 & 90.3 & 86.8 & 85.1 & 81.5 & 82.5 & 81.7 & 0 & .3 & 80.8 \\
\hline$u m$ & 14.8 & 14.7 & 14.4 & 14.4 & 14.8 & 14.8 & 15.3 & 15.1 & $19.9 \quad 9.4$ & & 89.3 & 90.0 & 85.4 & 84.2 & 81.8 & 81.7 & 79.8 & 1.2 & 30.4 & 80.0 \\
\hline & 12.6 & 12.8 & 12.7 & 12.4 & 11.6 & 12.3 & 12.9 & 11.2 & 16.911 .9 & 11.6 & & 94.6 & 87.3 & 85.3 & 83.1 & 83.7 & 79.8 & 2.4 & 81.0 & 82.0 \\
\hline & 11.9 & 12.2 & 11.5 & 11.1 & 11.9 & 12.3 & 12.7 & 11.6 & $\begin{array}{lll}16.5 & 10.4\end{array}$ & 10.7 & 5.6 & & 87.1 & 84.7 & 83.6 & 83.7 & 80.8 & 82.0 & 81.3 & 82.2 \\
\hline aculatum & 13.1 & 12.9 & 12.9 & 12.8 & 12.2 & 12.4 & 13.3 & 13.2 & 17.414 .6 & 16.2 & 13.9 & 14.2 & & 90.6 & 85.0 & 84.4 & 82.2 & 3.5 & 82.7 & 82.5 \\
\hline & 14.1 & 14.1 & 14.3 & 14.8 & 13.7 & 14.2 & 14.3 & 15.4 & 18.316 .6 & 17.8 & 16.4 & 17.1 & 10.0 & & 83.1 & 83.3 & 80.3 & & .3 & 82.8 \\
\hline & 15.6 & 15.4 & 15.3 & 14.9 & 15.7 & 15.7 & 17.3 & 17.8 & $19.8 \quad 21.3$ & 20.9 & 19.1 & 18.5 & 16.7 & 19.1 & & 84.0 & 82.1 & 80.6 & 0.2 & 81.9 \\
\hline$E_{S}$ & 15.4 & 15.8 & 15.7 & 16.0 & 15.7 & 15.7 & 16.1 & 16.2 & 19.119 .9 & 21.0 & 18.3 & 18.3 & 17.5 & 18.9 & 18.1 & & 84.0 & 79.4 & 81.0 & 81.6 \\
\hline$P s$ & 19.0 & 19.1 & 18.6 & 20.1 & 19.9 & 20.1 & 19.8 & 19.1 & 21.421 .0 & 23.6 & 23.6 & 22.1 & 20.3 & 22.8 & 20.5 & 18.1 & & 80.2 & 80.3 & 79.9 \\
\hline & 17.9 & 17.9 & 17.3 & 17.9 & 17.5 & 18.3 & 17.7 & 18.6 & 21.320 .6 & 21.6 & 20.1 & 20.6 & 18.6 & 19.0 & 22.4 & 24.1 & 23.0 & & 81.2 & 79.9 \\
\hline & 19.8 & 19.7 & 19.5 & 19.1 & 21.3 & 21.6 & 20.2 & 19.9 & 22.322 .8 & 22.7 & 21.9 & 21.4 & 19.7 & 18.9 & 23.0 & 21.9 & 22.8 & 21.6 & & 80.0 \\
\hline Bacil & 18.5 & 18.5 & 18.1 & 19.4 & 16.9 & 16.1 & 16.0 & 17.0 & 19.422 .1 & 23.3 & 20.6 & 20.3 & 19.9 & 19.5 & 20.8 & 21.2 & 23.4 & 23.4 & 23.3 & \\
\hline
\end{tabular}

\footnotetext{
${ }^{a}$ The values on the upper right are uncorrected percentages of similarity, and the values on the lower left are percentages of difference corrected for multiple base
} changes by the method of Jukes and Cantor (16).

University of Konstanz; this strain was originally isolated by Bache and Pfennig from sediment obtained from the Jadebusen (North Sea, near Wilhelmshaven, Germany) $(11,31$; unpublished data) and cultivated as described above. $\mathrm{Pe}$ lobacter carbinolicus $\mathrm{GraBd} 1^{\mathrm{T}}$ (= DSM $2380^{\mathrm{T}}$ ) was obtained from the Deutsche Sammlung von Mikroorganismen und Zellkulturen $\mathrm{GmbH}$; the lyophilized cell material which was delivered was used directly for isolation of genomic DNA (32).

DNA isolation, PCR amplification, and sequencing analysis. Cells were lysed by incubating them in $2.5 \%$ (wt/vol) sodium dodecyl sulfate for $20 \mathrm{~min}$ at $60^{\circ} \mathrm{C}$. DNA was extracted from each crude lysate with a Prep-A-Gene kit as described in the instructions supplied by the manufacturer (BioRad, Munich, Germany). The PCR was performed by using 16S rDNA primers (17) which amplify the $16 \mathrm{~S}$ rRNA genes from position 28 to position 1491 (International Union of Biochemistry [IUB] nomenclature for Escherichia coli) of a broad range of microorganisms belonging to the domain Bacteria. The thermal profile used for amplification included 29 cycles of primer annealing at $48^{\circ} \mathrm{C}$ for $1 \mathrm{~min}$, primer extension at $72^{\circ} \mathrm{C}$ for 2 min, and denaturation at $94^{\circ} \mathrm{C}$ for $0.5 \mathrm{~min}$. The aqueous phases obtained from three PCR were combined, and the volume was brought to $2.5 \mathrm{ml}$ with sterilized distilled water. The PCR products were purified for subsequent sequence analysis with Centricon 100 columns as described by the manufacturer (Amicon, Witten, Germany). Sequencing reactions were performed nonradioactively by using a Taq Dye Cycle sequencing kit in accordance with the instructions of the manufacturer (Applied Biosystems, Weiterstadt, Germany), and the reaction products were separated by electrophoresis with an automatic sequence analyser (model 370; Applied Biosystems). Primers for the target regions from positions 343 to 357,519 to 536,907 to 926,1100 to 1115 , and 1385 to 1401 (IUB nomenclature for
E. coli) were used for sequencing (17). Sequences were obtained for both strands of each 16S rDNA.

Phylogenetic analysis. The 16S rDNA sequences of strains KySW2 $^{\mathrm{T}}$, Kyval, Gyprop ${ }^{\mathrm{T}}$, Kyprop, Gylac ${ }^{\mathrm{T}}$, and Gö11 and of Pelobacter carbinolicus $\mathrm{GraBd} 1^{\mathrm{T}}$ were aligned manually with reference sequences of various members of the Proteobacteria $(6,20)$. Levels of sequence similarity were calculated by comparing only those positions at which bases could be unambiguously aligned (960 nucleotides). Evolutionary distances between pairs of organisms were determined by using the Jukes-Cantor equation (16) and the DNADIST program of the PHYLIP version 3.5 package (Table 1) (8). A tree which estimated the phylogenetic relationships was derived by using the FITCH program of the same package, random-order input of sequences, and the global rearrangement option.

DNA-DNA hybridizations. DNA-DNA hybridization experiments were carried out by workers at the Identification Service of the Deutsche Sammlung von Mikroorganismen and Zellkulturen GmbH. Genomic DNAs were isolated by chromatography on hydroxyapatite, using the procedure of Cashion et al. (4). The DNA-DNA hybridization experiments were performed by the spectroscopic method of De Ley et al. (5), with the modifications described by $\mathrm{Huß}$ et al. (14), using a Gilford System 2600 spectrophotometer equipped with a Gilford model 2527-R thermoprogrammer and a plotter. The DNA concentration was $50 \mu \mathrm{g} / \mathrm{ml}$. The optimal temperature of renaturation $\left(70^{\circ} \mathrm{C}\right)$ was calculated from the average $\mathrm{G}+\mathrm{C}$ content of the samples by the formula of Gillis et al. (12). The DNA reassociation rate was calculated by regression analysis between 10 and $30 \mathrm{~min}$ after start of the reaction, using the computer program TRANSFER.BAS (15). The homology values were calculated with the formula of De Ley et al. (5). Each measurement was repeated three times. 


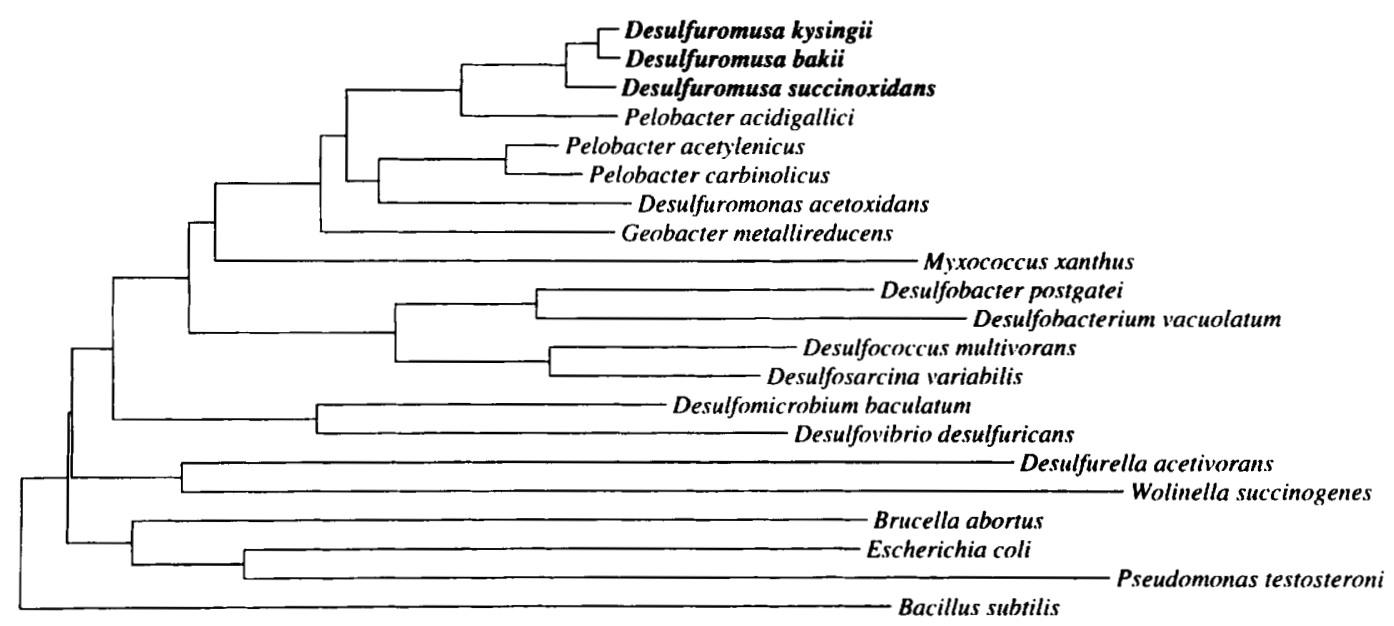

FIG. 1. Phylogenetic tree based on 16S rDNA sequences determined in this study for Desulfuromusa kysingii, Desulfuromusa bakii, Desulfuromusa succinoxidans and 18 reference organisms. Bar $=5 \%$ difference in nucleotide sequences, as determined by measuring the lengths of the horizontal lines connecting two species.

Nucleotide sequence accession numbers. The $16 \mathrm{~S}$ rDNA sequences of strains Gyprop ${ }^{T}$ and Kyprop were identical, as were the $16 \mathrm{~S}$ rDNA sequences of strains Kysw $2^{\mathrm{T}}$ and Kyval and the 16S rDNA sequences of strains Gylac $^{\mathrm{T}}$ and Gö11; the 16S rDNA sequences of these organisms and of Pelobacter carbinolicus GraBd1 $1^{\mathrm{T}}$ have been deposited in the EMBL data bank under accession numbers X79412 to X79415.

The EMBL and GenBank database accession numbers for the sequences used as reference sequences for phylogenetic tree construction (Table 1 and Fig. 1) are as follows: Bacillus subtilis, K00637; Brucella abortus, X13695; Desulfobacter postgatei, M26633; Desulfobacterium vacuolatum, M34408; Desulfococcus multivorans, M34405; Desulfomicrobium baculatum, M37311; Desulfosarcina variabilis, M26632; Desulfovibrio desulfuricans, M34113; Desulfurella acetivorans, X72768; Desulfuromonas acetoxidans, M26634; E. coli, J01695; Geobacter metallireducens, LO7834; Myxococcus xanthus, M34114; Pelobacter acidigallici, X77216; Pelobacter acetylenicus, X70955; Pseudomonas testosteroni, M11224; and Wolinella succinogenes, M26636.

\section{RESULTS AND DISCUSSION}

Our comparative sequence analysis of the almost complete 16S rRNA genes of strains Kysw2 ${ }^{\mathrm{T}}$, Kyval, Gyprop ${ }^{\mathrm{T}}$, Kyprop, and $\mathrm{Gylac}^{\mathrm{T}}$ revealed that these isolates, together with the previously not validly described organism strain Gö11, represent a coherent cluster of descent. Within this cluster the strains can be separated into three closely related but distinct rRNA groups, the Kysw $2^{\mathrm{T}}$-Kyval group, the Gyprop ${ }^{\mathrm{T}}$-Kyprop group, and the Gylac ${ }^{\mathrm{T}}$-Gö11 group; the members of each group have identical $16 \mathrm{~S}$ rDNA sequences. The overall levels of intergroup similarity for the almost completely analyzed $16 \mathrm{~S}$ rDNA sequences range from 98 to $99 \%$ for the three groups. Our phylogenetic treeing analysis confirmed the previous classification of strain Gö11 based on oligonucleotide cataloging data (11); we found that this organism belongs to a separate branch of the delta subgroup of the Proteobacteria which is characterized by species belonging to the genera Desulfuromonas and Pelobacter (Table 1 and Fig. 1). The members of these two genera exhibit fundamental differences in their biochemical and physiological properties. Desulfuromonas spp. are sulfur-respiring microorganisms that are capable of complete oxidation of substrates, whereas $\mathrm{Pe}$ lobacter spp. ferment a rather limited number of substrates (24-26). Our phylogenetic tree showed that members of these two genera not only have a common ancestor but also are phylogenetically interwined, as described previously $(7,28)$. On the one hand, the five new isolates and strain Gö11 are more closely related to Pelobacter acidigallici than to the type species of the genus Desulfuromonas, Desulfuromonas acetoxidans. On the other hand, the next most closely related phylogenetic neighbors of Desulfuromonas acetoxidans are the species Pelobacter acetylenicus and Pelobacter carbinolicus (Fig. 1). The five new isolates, strain Gö11, and Desulfuromonas acetoxidans completely oxidize acetate to $\mathrm{CO}_{2}$ with concomitant stoichiometric reduction of elemental sulfur to hydrogen sulfide. However, there are several differences among these organisms in the range of substrates utilized as electron donors (Table 2). In contrast to Desulfuromonas acetoxidans, neither the five new isolates nor strain Gö11 can utilize alcohols, while Desulfuromonas acetoxidans lacks the ability to oxidize dicarboxylic acids and amino acids. The five new isolates grow with fumarate or malate as the sole substrate, whereas Desulfuromonas acetoxidans can use these compounds only as electron acceptors. The $\mathrm{G}+\mathrm{C}$ contents of the five new strains and strain Gö11 are 46 to $47 \mathrm{~mol} \%$, whereas Desulfuromonas acetoxidans strains have $\mathrm{G}+\mathrm{C}$ contents of 50 to $52 \mathrm{~mol} \%$. Valid description of the five new isolates and strain Gö11 as members of the genus Desulfuromonas would require that the description of the genus Desulfuromonas be amended (21). Such a description would mean that the genus characteristics would have to be reduced to the main properties of the sulfur-reducing bacteria of the delta subclass of the Proteobacteria. The recently described organism Desulfuromonas acetexigens is phylogenetically interwined with Desulfuromonas acetoxidans and strain Gö11, as determined by oligonucleotide cataloging (11). Desulfuromonas acetexigens has a genomic DNA G $+\mathrm{C}$ content of 58.6 to $62.5 \mathrm{~mol} \%$ (10), meaning that the genus Desulfuromonas includes sulfur-reducing bacteria that have DNA base compositions ranging from 51 to $62.5 \mathrm{~mol} \%$. Description of the five new isolates and strain Gö11 as members of the genus 
TABLE 2. Major characteristics of the three species belonging to the genus Desulfuromusa and the type species of the genus Desulfuromonas, Desulfuromonas acetoxidans

\begin{tabular}{|c|c|c|c|c|}
\hline Characteristic & Desulfuromusa kysingii ${ }^{a}$ & Desulfuromusa bakii ${ }^{a}$ & Desulfuromusa succinoxidans ${ }^{a}$ & Desulfuromonas acetoxidans ${ }^{b}$ \\
\hline Morphology & Curved rods & Curved rods & Curved rods & Rods \\
\hline Width $(\mu \mathrm{m})$ & $0.5-0.6$ & $0.5-0.6$ & $0.8-1.0$ & $0.4-0.7$ \\
\hline Length $(\mu \mathrm{m})$ & $2-5$ & $2-4$ & $4-6$ & $1-4$ \\
\hline Motility ${ }^{c}$ & $+(\mathrm{sp})$ & $+(\mathrm{sp})$ & $+(\mathrm{sp})$ & $+(\operatorname{sp}$ or $\mathrm{sl})$ \\
\hline $\mathrm{G}+\mathrm{C}$ content of DNA (mol\%) & 47 & 46 & 46 & 51 \\
\hline Optimum pH & $6.5-7.9$ & $6.7-7.4$ & $6.5-7.9$ & $7.2-7.5$ \\
\hline Optimum temp $\left({ }^{\circ} \mathrm{C}\right)$ & $30-35$ & $25-30$ & $30-35$ & 30 \\
\hline Anaerobic oxidation of organic substrates & Complete & Complete & Complete & Complete \\
\hline \multicolumn{5}{|l|}{ Electron donors used for sulfur reduction ${ }^{d}$} \\
\hline Acetate & + & + & + & + \\
\hline Propionate & + & + & + & - \\
\hline Valerate & $(+)$ & - & - & - \\
\hline Citrate & + & + & - & - \\
\hline Ethanol & - & - & - & + \\
\hline Propanol & - & - & - & + \\
\hline \multicolumn{5}{|l|}{ Electron acceptors $b$} \\
\hline Sulfur & + & + & + & + \\
\hline Fumarate or malate & + & + & + & + \\
\hline Nitrate & + & - & - & - \\
\hline Dimethyl sulfoxide & + & - & - & - \\
\hline $\mathrm{Fe}(\mathrm{III})$-citrate & + & - & - & - \\
\hline \multicolumn{5}{|l|}{ Disproportionation } \\
\hline Fumarate, malate & + & + & + & - \\
\hline Aspartate, maleate & + & - & + & - \\
\hline Habitat(s) & $\begin{array}{l}\text { Anoxic marine or } \\
\text { estuarine mud }\end{array}$ & $\begin{array}{l}\text { Anoxic marine or } \\
\text { estuarine mud }\end{array}$ & Anoxic marine mud & $\begin{array}{l}\text { Anoxic marine or estuarine } \\
\text { mud }\end{array}$ \\
\hline Strain(s) & $\begin{array}{l}\text { DSM } 7343^{\mathrm{T}}(= \\
\left.\text { Kysw2 } 2^{\mathrm{T}}\right) \text {, DSM } \\
7344(=\text { Kyval })\end{array}$ & $\underset{\left.\text { Gyprop }^{\mathrm{T}}\right)}{\operatorname{DSM} 7345^{\mathrm{T}}}(=$ & DSM $8270\left(=\right.$ Gylac $\left.^{\mathrm{T}}\right)$ & DSM 684 \\
\hline
\end{tabular}

${ }^{a}$ Data from reference 9.

${ }^{b}$ Data from reference 21 .

${ }^{c}$ The flagellation pattern is indicated in parentheses (sl, single, lateral; sp, single, polar).

$d+$, utilized; $(+)$, utilized by some strains; - , not utilized. Other electron donors utilized by all Desulfuromusa species are succinate, fumarate, maleate, malate, oxalacetate, glutamate, aspartate, alanine, lactate, pyruvate, and yeast extract.

Desulfuromonas would mean that the range of the DNA base compositions of members of this genus would be 46 to 62.5 mol\%. This would be contrary to the now generally accepted opinion that species differing in their $\mathrm{G}+\mathrm{C}$ contents by more than 10 mol\% should not be placed in the same genus (13). In conclusion, the phenotypic characteristics of the five new isolates and strain Gö11 and the results of our phylogenetic analysis suggest that the sulfur-reducing bacteria under discussion should be placed into two different genera.

The levels of DNA-DNA relatedness of the five new isolates and strain Gö11 confirmed the comparative rDNA analysis results. The two strains of each of the three groups that have identical 16S rDNA sequences (strains Kysw2 ${ }^{\mathrm{T}}$ and Kyval, strains Gyprop ${ }^{T}$ and Kyprop, and strains Gylac $^{T}$ and Gö11) exhibited levels of DNA relatedness above the $70 \%$ threshold (29). However, the levels of DNA relatedness between the three rRNA groups were less than $30 \%$ (Table 3). Our results indicate that the five new isolates and strain Gö11 are members of three closely related but distinct genomic species. Phenotypically, the three species can be differentiated by differences in the following properties: use of nitrate, dimethyl sulfoxide, and $\mathrm{Fe}$ (III)-citrate as electron acceptors, use of citrate as an electron donor, and growth with aspartate or maleate as the sole substrate (Table 2).

Description of Desulfuromusa gen. nov. Desulfuromusa (De.sul.fu.ro.mu'sa. L. pref. de, from; L. n. sulfur, sulfur; M.L.n. musa, banana; M.L.f. n. Desulfuromusa, a bananashaped bacterium that reduces sulfur). Cells are motile and slightly curved or rod shaped; they stain gram negative and are obligately anaerobic. They do not form spores. Elemental sulfur is used as an electron acceptor and is reduced to hydrogen sulfide. No growth occurs when either sulfate, sulfite,

TABLE 3. Levels of DNA relatedness for Desulfuromusa kysingii Kysw2 ${ }^{\mathrm{T}}$ and Kyval, Desulfuromusa bakii Gyprop ${ }^{\mathrm{T}}$ and Kyprop, and Desulfuromusa succinoxidans Gylac ${ }^{\mathrm{T}}$ and Gö11

\begin{tabular}{|c|c|c|c|c|c|c|c|}
\hline \multirow{2}{*}{ Source of chromosomal DNA } & \multirow{2}{*}{$\begin{array}{l}\mathrm{G}+\mathrm{C} \text { content } \\
\quad(\mathrm{mol} \%)\end{array}$} & \multicolumn{6}{|c|}{$\%$ Reassociation with DNA from ${ }^{a}$ : } \\
\hline & & Strain Kysw $2^{\mathrm{T}}$ & Strain Kyval & Strain Gyprop $^{T}$ & Strain Kyprop & Strain Gylac ${ }^{\mathrm{T}}$ & Strain Gö11 \\
\hline Desulfuromusa kysingii Kysw $2^{\mathrm{T}}$ & 47 & 100 & 89 & 24 & 19 & 21 & $\mathrm{ND}^{b}$ \\
\hline Desulfuromusa bakii Gyprop ${ }^{T}$ & 46 & 24 & ND & 100 & 98 & 25 & ND \\
\hline Desulfuromusa succinoxidans Gylac ${ }^{\mathrm{T}}$ & 46 & 21 & ND & 25 & ND & 100 & 73 \\
\hline
\end{tabular}

${ }^{a}$ The levels of reassociation were determined as described in Materials and Methods.

${ }^{b} \mathrm{ND}$, level of DNA relatedness not determined 
thiosulfate, tetrathionate, trimethylammonium oxide, cystine, oxidized glutathione, $\mathrm{N}_{2} \mathrm{O}$, or oxygen is added as an electron acceptor. Growth occurs with fumarate or malate as the sole substrate. Short-chain fatty acids, dicarboxylic acids, and amino acids are used as electron donors and are oxidized completely to $\mathrm{CO}_{2}$. Alcohols and sugars are not utilized. Growth occurs with elemental sulfur; in liquid medium the bacteria are closely attached to elemental sulfur, which is used as an electron acceptor. In agar medium the strains form whitish filamentous colonies. Growth with fumarate as the sole substrate: the generation times with fumarate are generally shorter than the generation times with elemental sulfur. In agar medium the peach-colored colonies are lens shaped and have entire edges. Phylogenetically, the genus belongs to a lineage of the delta subclass of the Proteobacteria characterized by members of the genera Desulfuromonas and Pelobacter. The $\mathrm{G}+\mathrm{C}$ content of the DNA of the type species is 47 mol\%. The type species is Desulfuromusa kysingii.

On the basis of DNA-DNA relatedness data and phenotypic characteristics, three different species of the genus Desulfuromusa are described below.

Description of Desulfuromusa kysingii sp. nov. Desulfuromusa kysingii (ky. sin'gi.i. M. L. gen. n. kysingii, of kysing, named after the Fjord south of Arhus [Jutland, Denmark] from which the organism was isolated). Cells are 0.5 to $0.6 \mu \mathrm{m}$ wide and 2 to $4 \mu \mathrm{m}$ long when they are grown on elemental sulfur as the electron acceptor. Type strain Kysw2 cells are motile by means of a single, subpolarly inserted flagellum. Nitrate, dimethyl sulfoxide, and Fe(III)-citrate are utilized as electron acceptors and are reduced to ammonia, dimethyl sulfide, and dissolved Fe(II), respectively. Cells grow with aspartate or maleate without additional electron acceptors, but growth is considerably slower than growth in the presence of elemental sulfur. Citrate, acetate, pyruvate, lactate, propionate, oxalacetate, succinate, maleate, alanine, glutamate, aspartate, and yeast extract are used as electron donors. Strains can be cultivated in defined medium without addition of complex nutrients like yeast extract or peptone. Cells grow in the presence of $\mathrm{NaCl}$ and $\mathrm{MgCl}_{2}$ concentrations of 114 and 3.3 $\mathrm{mM}$, respectively. Oxygen $(2 \%)$ is tolerated, but no growth occurs in the presence of this compound. Strain Kysw $2^{\mathrm{T}}$ cells are able to grow diazotrophically and require $p$-aminobenzoate. The optimum $\mathrm{pH}$ for growth is between 6.5 and 7.9 ; the minimum and maximum $\mathrm{pH}$ values for growth are 5.8 and 8.25 , respectively. The minimum temperature for growth is $4^{\circ} \mathrm{C}$; the maximum temperature is $35^{\circ} \mathrm{C}$; and the optimum temperature is around $32^{\circ} \mathrm{C}$.

Desulfuromusa kysingii Kysw2 (= DSM 7343) is the type strain; the $\mathrm{G}+\mathrm{C}$ content of its DNA is $47 \mathrm{~mol} \%$.

The habitat of Desulfuromusa kysingii Kysw2 $2^{\mathrm{T}}$ and Kyval is the anoxic mud of the Kysing Fjord south of Århus, Denmark.

Description of Desulfuromusa bakii sp. nov. Desulfuromusa bakii (ba'ki.i. M. L. gen.n. bakii, of Bak, named in memory of Friedhelm Bak, who made important contributions to our knowledge of sulfur- and sulfate-reducing bacteria). Cells are 0.5 to $0.6 \mu \mathrm{m}$ wide and 2 to $4 \mu \mathrm{m}$ long when they are grown with elemental sulfur as the electron acceptor. Nitrate, dimethyl sulfoxide and Fe(III)-citrate are not utilized as electron acceptors. No growth occurs with aspartate or maleate without additional electron acceptors. Citrate, acetate, pyruvate, lactate, propionate, oxalacetate, succinate, maleate, alanine, glutamate, aspartate, and yeast extract are used as electron donors. Strains can be cultivated in defined medium without addition of complex nutrients like yeast extract or peptone. No growth occurs in the presence of $\mathrm{NaCl}$ and $\mathrm{MgCl}_{2}$ concentrations of 114 and $3.3 \mathrm{mM}$, respectively. The optimum $\mathrm{pH}$ for growth is between 6.7 and 7.4, and the minimum and maximum $\mathrm{pH}$ values for growth are 6.2 and 7.8 , respectively. The minimum temperature for growth is $8^{\circ} \mathrm{C}$; the maximum temperature for growth is $32^{\circ} \mathrm{C}$; and the optimum temperature is between 25 and $30^{\circ} \mathrm{C}$.

The type strain of Desulfuromusa bakii is strain Gyprop (= DSM 7345); the G+C content of its DNA is 46 mol\%.

Desulfuromusa bakii Gyprop ${ }^{\mathbf{T}}$ was isolated from an anoxic mud sample collected from Guayamas Basin (Gulf of California) at a depth of about $2,000 \mathrm{~m}$. The habitat of Desulfuromusa bakii Kyprop is the anoxic mud of the shallow Kysing Fjord south of Århus, Denmark.

Description of Desulfuromusa succinoxidans sp. nov. Desulfuromusa succinoxidans (suc.cin.ox'i.dans. L. n. succinum, amber; M.L. n. acidum succinicum, succinic acid [derived from amber]; M.L. v. oxido, make acid, oxidize; M.L. part.adj. succinoxidans, oxidizing succinate). Cells are 0.8 to $1.0 \mu \mathrm{m}$ wide and 4 to $6 \mu \mathrm{m}$ long when they are grown on elemental sulfur as the electron acceptor. Nitrate, dimethyl sulfoxide, and $\mathrm{Fe}(\mathrm{III})$-citrate are not utilized. Cells grow with aspartate or maleate without additional electron acceptors, but growth is considerably slower than growth in the presence of elemental sulfur. Acetate, pyruvate, lactate, propionate, oxalacetate, succinate, maleate, alanine, glutamate, aspartate, and yeast extract are used as electron donors. Citrate is not utilized as an electron donor. Strains can be cultivated in defined medium without addition of complex nutrients like yeast extract or peptone. Cells grow in the presence of $\mathrm{NaCl}$ and $\mathrm{MgCl}_{2}$ concentrations of 114 and $3.3 \mathrm{mM}$, respectively. The optimum $\mathrm{pH}$ for growth is between 6.5 and 7.9 ; minimum and maximum $\mathrm{pH}$ values for growth are 5.8 and 8.25 , respectively. The minimum temperature for growth is $4^{\circ} \mathrm{C}$; the maximum temperature is $35^{\circ} \mathrm{C}$; and the optimum temperature is around $32^{\circ} \mathrm{C}$.

The type strain of Desulfuromusa succinoxidans is strain Gylac (= DSM 8270); the G+C content of its DNA is 46 $\mathrm{mol} \%$.

Desulfuromusa succinoxidans Gylac $^{\mathrm{T}}$ was isolated from an anoxic mud sample collected at a depth of about 2,000 m from the Guayamas Basin (Gulf of California).

\section{ACKNOWLEDGMENTS}

Sonja Fleissner is acknowledged for her technical assistance. We are indebted to $\mathrm{N}$. Pfennig for helpful discussions and for the Latin derivations of the new bacterial names. Kai Finster thanks Ralf Conrad and members of his group for support. The help of B. B. Jørgensen is greatly appreciated

Kai Finster was supported by grant 11-8588 from the Danish National Science Council and the Danish Research Academy.

\section{REFERENCES}

1. Balashova, V. V. 1985. The use of molecular sulfur as an agent oxidizing hydrogen by the facultative anaerobic Pseudomonas strain. Mikrobiologiya 54:324-326.

2. Biebl, H., and N. Pfennig. 1977. Growth of sulfate-reducing bacteria with sulfur as electron acceptor. Arch. Microbiol. 112: 115-117.

3. Bonch-Osmolovskaya, E. A., T. G. Sokolova, N. A. Kostrikina, and G. A. Zavarzin. 1990. Desulfurella acetivorans gen. nov. and sp. nov., a new thermophilic sulfur-reducing eubacterium. Arch. Microbiol. 153:151-155.

4. Cashion, P., M. A. Holder-Franklin, J. McCully, and M. Franklin. 1977. A rapid method for the base ratio determination of bacterial DNA. Anal. Biochem. 81:461-466.

5. De Ley, J., H. Cattoir, and A. Reynaerts. 1970. The quantitative measurement of DNA hybridization from renaturation rates. Eur. J. Biochem. 12:133-142.

6. De Rijk, P., J.-M. Neefs, Y. Van de Peer, and R. De Wachter. 1992. 
Compilation of small ribosomal subunit RNA sequences. Nucleic Acids Res. 20:2075-2089.

7. Evers, S., M. Weizenegger, W. Ludwig, B. Schink, and K.-H. Schleifer. 1993. The phylogenetic positions of Pelobacter acetylenicus and Pelobacter propionicus. Syst. Appl. Microbiol. 16:216-218.

8. Felsenstein, J. 1989. PHYLIP-phylogeny inference package (version 3.2). Cladistics 5:164-166

9. Finster, K., and F. Bak. 1993. Complete oxidation of propionate, valerate, succinate, and other organic compounds by newly isolated types of marine, anaerobic, mesophilic, gram-negative, sulfur-reducing eubacteria. Appl. Environ. Microbiol. 59:1452-1460.

10. Finster, K., F. Bak, and N. Pfennig. 1994. Desulfuromonas acetexigens sp. nov., a dissimilatory sulfur-reducing eubacterium from anoxic freshwater sediments. Arch. Microbiol. 161:328-332.

11. Fowler, V. J., F. Widdel, N. Pfennig, C. R. Woese, and E. Stackebrandt. 1986. Phylogenetic relationships of sulfate- and sulfur-reducing eubacteria. Syst. Appl. Microbiol. 8:32-41.

12. Gillis, M., J. De Ley, and M. De Cleene. 1970. The determination of molecular weight of bacterial genome DNA from renaturation rates. Eur. J. Biochem. 12:143-153.

13. Goodfellow, M., and A. G. O'Donnell. 1993. Roots of bacterial systematics, p. 3-56. In M. Goodfellow and A. G. O'Donnell (ed.), Handbook of new bacterial systematics. Academic Press, New York.

14. Huß, V. A. R., H. Festl, and K. H. Schleifer. 1983. Studies on the spectrophotometric determination of DNA hybridization from renaturation rates. Syst. Appl. Microbiol. 4:184-192.

15. Jahnke, K.-D. 1992. BASIC computer program for evaluation of spectroscopic DNA renaturation data from GILFORD SYSTEM 2600 spectrophotometer on a PC/XT/AT type personal computer. J. Microbiol. Methods 15:61-73.

16. Jukes, T. H., and C. R. Cantor. 1969. Evolution of protein molecules, p. 21-132. In H. N. Munro (ed.), Mammalian protein metabolism, vol. 3. Academic Press, Inc., New York.

17. Lane, D. J. 1991. 16S/23S rDNA sequencing, p. 115-176. In E. Stackebrandt and M. Goodfellow (ed.), Nucleic acid techniques in bacterial systematics. Wiley \& Sons, Chichester, England.

18. Miroshnichenko, M. L., G. A. Gongadze, A. M. Lysenko, and E. A. Bonch-Osmolovskaya. 1994. Desulfurella multipotens sp. nov., a new sulfur-respiring thermophilic eubacterium from Raoul Island (Kermadec archipelago, New Zealand). Arch. Microbiol. 161:8893.

19. Myers, C. R., and K. H. Nealson. 1988. Bacterial manganese reduction and growth with manganese oxide as sole electron acceptor. Science 240:1319-1321.

20. Olsen, G. J., R. Overbeek, N. Larsen, T. L. Marsh, M. J. McCaughey, M. A. Maciukenas, W. M. Kuan, T. J. Macke, and C. R. Woese. 1992. The ribosomal data base project. Nucleic Acids Res. 20(Suppl.):2199-2200.

21. Pfennig, N., and H. Biebl. 1976. Desulfuromonas acetoxidans gen. nov, and sp. nov., a new anaerobic, sulfur-reducing, acetateoxidizing bacterium. Arch. Microbiol. 110:3-12.

22. Pfennig, N., and H. Biebl. 1981. The dissimilatory sulfur-reducing bacteria, p. 941-947. In M. P. Starr, H. Stolp, H. G. Trüper, A. Balows, and H. G. Schlegel (ed.), The prokaryotes, vol. 1. Springer-Verlag, Berlin.

23. Rainey, F. A., R. Toalster, and E. Stackebrandt. 1993. Desulfurella acetivorans, a thermophilic, acetate-oxidizing and sulfur-reducing organism, represents a distinct lineage within the Proteobacteria. Syst. Appl. Microbiol. 16:373-379.

24. Schink, B. 1984. Fermentation of 2,3-butandiol by Pelobacter carbinolicus sp. nov. and Pelobacter propionicus sp. nov., and evidence for propionate formation from $\mathrm{C}_{2}$ compounds. Arch Microbiol. 137:33-41.

25. Schink, B. 1985. Fermentation of acetylene by an obligate anaerobe, Pelobacter acetylenicus sp. nov. Arch. Microbiol. 142:295-301.

26. Schink, B., and N. Pfennig. 1982. Fermentation of trihydroxybenzenes by Pelobacter acidigallici gen. nov., sp. nov., a strictly anaerobic, non-sporeforming bacterium. Arch. Microbiol. 133: 195-201.

27. Schumacher, W., P. M. H. Kroneck, and N. Pfennig. 1992 Comparative systematic study on "Spirillum" 5175, Campylobacter and Wolinella species. Description of "Spirillum" 5175 as Sulfurospirillum deleyianum gen. nov., spec. nov. Arch. Microbiol. 158: 287-293.

28. Stackebrandt, E., U. Wehrmeyer, and B. Schink. 1989. The phylogenetic status of Pelobacter acidigallici, Pelobacter venetianus, and Pelobacter carbinolicus. Syst. Appl. Microbiol. 11:257-260.

29. Wayne, L. G., D. J. Brenner, R. R. Colwell, P. A. D. Grimont, O. Kandler, M. I. Krichevsky, L. H. Moore, W. E. C. Moore, R. G. E. Murray, E. Stackebrandt, M. P. Starr, and H. G. Trüper. 1987. Report of the Ad Hoc Committee on Reconciliation of Approaches to Bacterial Systematics. Int. J. Syst. Bacteriol. 37:463464.

30. Widdel, F. 1988. Microbiology and ecology of sulfate-and sulfurreducing bacteria, p. 469-585. In A. J. B. Zehnder (ed.), Biology of anaerobic microorganisms. John Wiley \& Sons, Inc., New York.

31. Widdel, F., and N. Pfennig. 1992. The genus Desulfuromonas and other Gram-negative sulfur-reducing eubacteria, p. 3379-3389. In A. Balows, H. G. Trüper, M. Dworkin, W. Harder, and K. H. Schleifer (ed.), The prokaryotes, 2nd ed., vol. 4. Springer, New York.

32. Wisotzkey, J. D., P. Jurtshuk, Jr., and G. E. Fox. 1990. PCR amplification of $16 \mathrm{~S}$ rDNA from lyophilized cell cultures facilitates studies in molecular systematics. Curr. Microbiol. 21:325327.

33. Wolfe, R. S., and N. Pfennig. 1977. Reduction of sulfur by Spirillum 5175 and syntrophism with Chlorobium. Appl. Environ. Microbiol. 33:427-433. 